\title{
EFFECTS OF TRAFFIC NOISE ON SLEEP IN AN URBAN POPULATION
}

\author{
Ljiljana STOŠIĆ ${ }^{1}$, Goran BELOJEVIĆ , and Suzana MILUTINOVIĆ ${ }^{1}$ \\ Institute of Public Health, Nišr , Institute of Hygiene and Medical Ecology, School of Medicine, \\ University of Belgrade, Belgrade ${ }^{2}$, Serbia
}

Received in March 2009

Accepted in July 2009

\begin{abstract}
Urban noise is an important environmental stressor, and sleep disturbance is its major health effect. Substantial inter-individual variance in these effects might partly be explained by different sensitivity to noise. The aim of this study was to assess the effects of urban noise on sleep and the relation between selfestimated sensitivity to noise and sleep disturbance. A cross-sectional questionnaire survey was performed on 911 adult residents of Niš, Serbia, of whom 388 were men (42.6\%) and 523 women $(57.4 \%)$. The streets were regarded as noisy if night equivalent noise level (Leq) was higher than $45 \mathrm{~dB}(\mathrm{~A})$ and quiet if night Leq was $\leq 45 \mathrm{~dB}(\mathrm{~A})$. Noise sensitivity was measured with the Weinstein's Noise Sensitivity Scale. The study showed that respondents from noisy area significantly more often reported difficulty in falling asleep, being woken up, poor sleep quality, tiredness after sleep, and use of sleep medication than residents from quiet streets $(p<0.001)$. Noise sensitivity significantly correlated with sleep disturbances $(p<0.001)$.
\end{abstract}

KEY WORDS: adults, public health, sensitivity, sleep disturbance

Urban noise is a major environmental problem, mainly due to intense road and air traffic. Among the most important health effects of urban noise is sleep disturbance $(1,2)$. Every third EU resident complains about sleep disturbed by night noise exceeding the level of $55 \mathrm{~dB}(\mathrm{~A})$. However, in up to $90 \%$ of noise-induced sleep disturbances other factors may act as confounders, such as worries, anxiety, distress, depression, painful illnesses, bad indoor climate, low quality mattress and/or pillow, artificial light, alcoholism, taking naps during the day, psychostimulants, jet lag, exercising before bedtime, low socioeconomic status, and too long television viewing (3).

There is a substantial inter-individual variance in noise effects on sleep, and various covariates have been investigated such as health status, age, and sex. Generally speaking, more pronounced effects of noise on sleep may be expected in elderly women and in people with chronic illnesses (4). A less known factor that might explain a part of this variance might be noise sensitivity interpreted as an attitude toward noise in general, differing from noise annoyance which is a reaction to specific noise (5). In 1966, Mc Kennell and Hunt used a term "subjective noise sensitivity"(6) and Heinonen-Guzejev described noise sensitivity as a relatively stable individual trait, independent of noise exposure and under significant genetic influence (7). Longer questionnaires such as Weinstein's Noise Sensitivity Scale have been shown to have better predictability of annoyance reactions to noise than short questionnaires $(8,9)$. A relative consistency and stability in noise sensitivity has been supported by a high correlation (men $=0.63$, women $=0.74$ ) of test-re-test scores on Noise Sensitivity Scale among London residents after a three-year period (10). Previous studies showed that noise sensitivity affects the degree of annoyance with noise and that people sensitive to noise are more annoyed with noise than non-sensitive people at similar exposure levels, after 
adjustment for relevant confounders $(11,12)$. Noise annoyance as a negative attitude towards a specific noise or noisy environments may enhance arousal and disturb sleep more frequently in noise-sensitive people than in non-sensitives (13).

The aim of this study was to investigate the effects of noise on sleep in an urban population and the relation between noise sensitivity and sleep disturbance.

\section{SUBJECTS AND METHODS}

\section{Noise measurements}

Traffic noise was measured at six sites in the centre of Niš, of which three were in the city's busiest streets and three in quiet side streets. Measurements were done with a Brüel \& Kjær noise level analyzer type 4426 in accordance with Serbian and ISO noise regulations $(14,15)$. The total number of samples was 9000 , with a period of sampling $0.1 \mathrm{~s}$ in a fast dynamic range during two night-time intervals $(22.00 \mathrm{~h}$ to 01.00 $\mathrm{h}$ and $02.00 \mathrm{~h}$ to $05.00 \mathrm{~h}$ ). From two equivalent noise levels (Leq), we calculated a composite night Leq using the following formula:

$$
\mathrm{L}_{\mathrm{eq}}=10 \log _{10}\left(\sum_{i=1}^{n} t_{i} 10^{\substack{L_{j} \\ 10}}\right) \mathrm{dB}(\mathrm{A})
$$

where $t_{i}$ is the part of total measuring time (0.5) in which a constant level $\mathrm{L}_{\mathrm{i}}$ was found (Leq in one of the two intervals). Leq is formulated in terms of equivalent steady noise level which in a stated period of time would contain the same noise energy as the time-varying noise during the same time period.

Streets with night Leq $>45 \mathrm{~dB}(\mathrm{~A})$ were regarded noisy and those with night Leq $\leq 45 \mathrm{~dB}(\mathrm{~A})$ were regarded quiet, in accordance with WHO recommendations (3) and Serbian regulation on night noise limits in residential areas (16).

\section{Study design}

This study was designed as a cross-sectional questionnaire survey among residents of the centre of a Serbian city of Niš with about 253,000 inhabitants, which makes it the third largest city in the country.

A total of 3000 questionnaires were distributed to residents of three busy streets and three quiet side streets, who served as control. The number of distributed questionnaires corresponded to the number of adult dwellers in each flat. The residents were asked to fill out the questionnaires by the next day, when these were collected.

Residents had to live at the current address for over a year and to have their bedroom windows face the street. The exclusion criteria were chronic diseases that might cause sleep disturbances and hearing loss.

Of 3000 distributed questionnaires, 1063 were completed (35.4\%), but applying exclusion criteria, the study included 911 participants, of whom 388 (42.6\%) were men and 523 (57.4\%) women. 463 participants lived in noisy streets and 448 participants in quiet streets.

\section{The questionnaire}

The first section of the questionnaire was related to general demographic data, whether the bedroom faced the street or not, presence of chronic diseases that might cause sleep disturbance, and hearing loss. In the sleep section of the questionnaire, the participants were asked about average duration of night sleep, difficulties in falling asleep (1 - not at all; 2 - generally no; 3 - generally yes; 4 - very much), average time to fall asleep, average number of night awakenings, subjective sleep quality (1 - very bad; 2 - bad; 3 - changeable; 4 - good; 5 - excellent), tiredness after sleep (1 - very tired; 2 - tired; 3 - changeable; 4 - restful, 5 - completely restful) use of sleeping pills (1 - every day; 2 - several times a week; 3 - several times a month; 4 - rarely), and whether residents kept bedroom windows open at night in the summer.

To assess sensitivity to noise, the questionnaire included 21 questions, whose answers were scored using the original Weinstein's Noise Sensitivity Scale (8). This scale has already proven to have satisfactory psychometric properties, that is, reliability, internal consistency, factor structure, and construct validity (17).

A verbal (not at all; slightly; moderately; very; extremely) and a numeric noise annoyance scales (from 0 - not at all, to 10 - extremely) were used (18).

\section{Statistical analysis}

We used Student's $t$-test to compare the means of numeric variables age, time spent in the flat every day, and duration of sleep with normal distribution between the two independent samples of residents from the noisy and the quiet area with normal distribution. Mann-Whitney U test was used to 
compare the means of numeric variables apartment size, period of residence, and time to fall asleep with asymmetric distribution between the two independent samples. Differences in the distribution of categorical variables sex distribution, education level, difficulty falling asleep, night awakenings, sleep by the open window, and use of sleeping pills between the two independent samples (noisy and quiet area) were tested with Pearson's chi-square test, using Yates' correction. Correlation between scores was tested with Spearman's test (noise sensitivity and sleep disturbances). A probability of error of less than $5 \%$ $(\mathrm{p}<0.05)$ was accepted as significant. All statistical analyses were performed using SPSS (version 10.0) and Statcalc from EPI-INFO (version 6) statistical computer programs.

\section{RESULTS}

Noise measurements showed that the average night Leq was significantly higher in noisy streets than in quiet streets $[(61.33 \pm 2.31) \mathrm{dB}(\mathrm{A})$ vs. $(43 \pm 3.46) \mathrm{dB}(\mathrm{A})$ respectively; $\mathrm{p}=0.043$, Student's $t$-test].

A comparison of demographic data between the groups showed that noisy area residents were four years older on average, enjoyed fewer square metres of flat area per tenant, and fewer of them had only elementary school education than quiet area residents (Table 1).

Noise annoyance reports showed that noisy area residents were more frequently highly annoyed with noise than quiet area residents (Pearson's chisquare $=150.25 ; p<0.001$ ) (Figure 1).
Noisy area residents needed more time to fall asleep, woke more often at night, consumed sleeping pills more often, and kept the windows open in the summer less often than quiet area residents (Table 2).

Sleep quality reports showed that noisy area residents more frequently assessed their sleep as bad (Pearson's chi-square $=40.54 ; p<0.001$ ) (Figure 2) whereas $15.1 \%$ of noisy area residents reported tiredness after sleep, in comparison with $6.0 \%$ from quiet streets (chi-square $=52.65 ; \mathrm{p}<0.001$ ).

Average noise sensitivity score of noisy area residents was significantly higher than of quiet area residents [(89.3 \pm 17.7$)$ vs. $(79.7 \pm 20.3)$, respectively; Mann-Whitney U test, $\mathrm{Z}=5.46, \mathrm{p}<0.001]$.

A correlation analysis between noise sensitivity and sleep disturbance showed a highly significant positive relation, except for the duration of night sleep and the number of awakenings. It should be noted that the number of people with night awakenings was much lower (159 persons), with lower statistical power compared to other correlation analyses performed on more than 900 people (Table 3).

\section{DISCUSSION}

This study in a population of Niš has shown that noise might significantly contribute to sleep disturbance. This is in accordance with a previous study on a smaller population sample from Belgrade (19). These studies in the largest urban agglomerations in Serbia are a sound scientific basis for introducing the EU Noise Directive (20), an environmental regulation

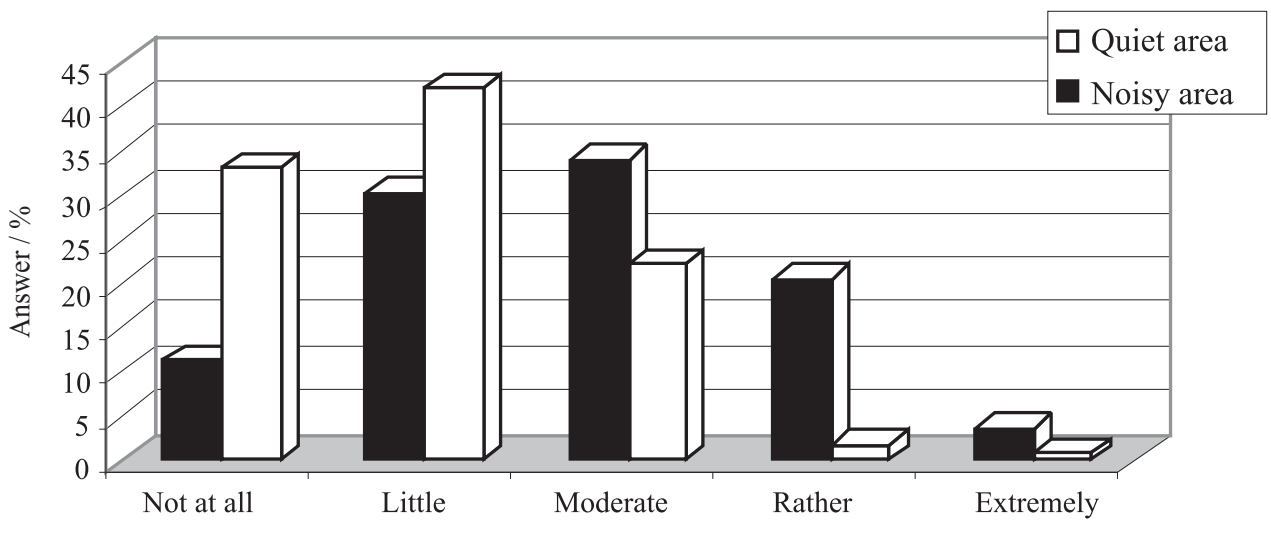

Noise annoyance

Figure 1 Distribution of answers from a questionnaire on noise annoyance among noisy [night Leq $>45 \mathrm{~dB}(A)]$ and quiet area residents [night Leq $\leq 45 d B(A)]$ in Niš $($ mean $\pm S D)$ [N=911] 
Table 1 Basic demographic data about noisy [night Leq $>45 d B(A)]$ and quiet area residents [night Leq $\leq 45 d B(A)]$ in Niš $(m e a n \pm S D)$

\begin{tabular}{lccc}
\hline Variable & $\begin{array}{c}\text { Noisy Streets } \\
(\mathbf{N = 4 6 3 )}\end{array}$ & $\begin{array}{c}\text { Quiet Streets } \\
(\mathbf{N}=\mathbf{4 4 8})\end{array}$ & $\mathbf{p}$ \\
\hline Age / years & $45.00 \pm 16.32$ & $41.71 \pm 13.64$ & $<0.01^{*}$ \\
Males & $204(44.10 \%)$ & $184(41.10 \%)$ & $>0.05^{\#}$ \\
Apartment size / $\mathrm{m}^{2}$ per tenant & $63.28 \pm 18.31$ & $77.67 \pm 30.18$ & $<0.001^{\$}$ \\
Period of residence / years & $17.89 \pm 13.03$ & $17.92 \pm 11.64$ & $>0.05^{\S}$ \\
Daily time spent in apartment / h & $14.45 \pm 3.44$ & $14.18 \pm 3.11$ & $>0.05^{*}$ \\
Education / \% & & & \\
$\quad$ Elementary & 1.9 & 4.9 & $<0.05^{\#}$ \\
Secondary & 59.8 & 58.3 & \\
Higher & 10.8 & 13.4 & \\
$\quad$ University & 27.4 & 23.4 & \\
\hline
\end{tabular}

*Student's t-test

"Pearson's chi-square test

${ }^{s}$ Mann-Whitney U-test

Table 2 Sleep characteristics among noisy [night Leq $>45 d B(A)$ ] and quiet area residents [night Leq $\leq 45 d B(A)]$ in Niš (mean $\pm S D$ )

\begin{tabular}{lccc}
\hline Sleep parameters & $\begin{array}{c}\text { Noisy Streets } \\
(\mathbf{N}=\mathbf{4 6 3})\end{array}$ & $\begin{array}{c}\text { Quiet Streets } \\
(\mathbf{N}=\mathbf{4 4 8})\end{array}$ & p \\
\hline Duration of sleep / h & $6.97 \pm 1.28$ & $7.04 \pm 1.15$ & $>0.05^{*}$ \\
Difficulties in falling asleep / \% & 36.90 & 7.40 & $<0.001^{\#}$ \\
Time to fall asleep / min) & $22.85 \pm 17.22$ & $16.58 \pm 13.85$ & $<0.001^{\text {s }}$ \\
Night awakenings / \% & 27.60 & 6.9 & $<0.001^{\#}$ \\
Sleep by open window / \% & 57.50 & 65.20 & $<0.05^{\#}$ \\
Usage of sleeping pills / \% & 28.30 & 17.40 & $<0.001^{\#}$ \\
\hline
\end{tabular}

*Student's t-test

"Pearson's chi-square test

${ }^{\$}$ Mann-Whitney U-test

Table 3 Correlation analysis between noise sensitivity and sleep disturbance in a sample of Niš residents

\begin{tabular}{lccc}
\hline Variables & N & Spearman R & p \\
\hline Duration of night sleep & 908 & 0.020 & $>0.050$ \\
Difficulties in falling asleep & 908 & 0.334 & $<0.001$ \\
Time to fall asleep & 908 & 0.347 & $<0.001$ \\
Number of awakenings & 159 & 0.136 & $>0.050$ \\
Subjective sleep quality & 908 & -0.292 & $<0.001$ \\
Tiredness upon awakening & 908 & -0.201 & $<0.001$ \\
Sleeping pills & 907 & -0.250 & $<0.001$ \\
\hline
\end{tabular}

obligatory for all countries intending to join the EU. In this directive, sleep disturbance is considered a major health effect of night traffic noise, which needs to be followed up in agglomerations exceeding 200.000 inhabitants.

Investigations in other European cities have also identified traffic noise as a cause of sleep disturbance in urban population. In Valencia, about $49 \%$ of adults complained of night awakenings by traffic noise in the 1990s (21). Residents of Gothenburg, who lived near a highway, with 24-hour Leq of $72 \mathrm{~dB}(\mathrm{~A})$ reported worse sleep quality and more pronounced tiredness after sleep than people from a quiet area, [24-hour Leq=56 dB(A)]. A significant improvement in reported sleep quality was established after noise counter-measures were implemented in 


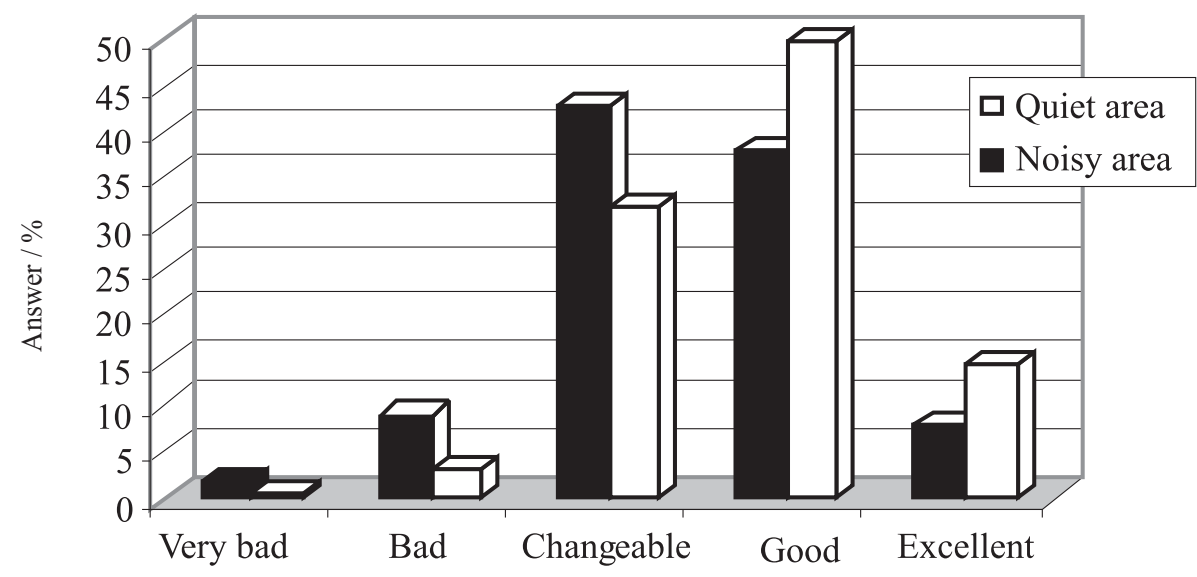

Self-reported sleep quality

Figure 2 Self-reported sleep quality among noisy [night Leq $>45 d B(A)]$ and quiet area residents [night Leq $\leq 45 d B(A)]$ in Niš (mean $\pm S D)[N=911]$

the investigated noisy area (22). The consumption of sedatives among people living around Schiphol airport in Amsterdam was significantly greater than in control residents exposed to low aircraft noise (23). In another postal questionnaire survey in Gothenburg, long-term effects of noise were tiredness in the morning and depression (24).

The pathophysiological basis of the disturbing effects of noise on sleep is the stimulation of hypothalamo-pituitary-adrenal axis and reticular formation through acoustical pathways. Instead of giving acoustic information, unwanted sound turns into nuisance after its processing in temporal areas of the brain cortex. The general physiological effect is greater arousal or psycho-physiological excitation and frequent occurrence of arousal triggered by night time noise disturbs the circadian rhythm. This might affect sleep in all its phases (25).

Our results showing positive and significant correlation between noise sensitivity and noiseinduced sleep disturbance are supported by the findings of an experimental investigation on humans exposed to night time noise of $39 \mathrm{~dB}(\mathrm{~A})$ to $50 \mathrm{~dB}(\mathrm{~A})$. In this study, correlations were found between noise sensitivity and self-reported sleep quality and difficulty falling asleep (26). Another laboratory study also confirmed a significant influence of noise sensitivity on sleep disturbance (27). The relation between noise sensitivity and noise annoyance has been shown to be very strong (5) and might give a clue for understanding individual differences in sleep in noise. Although annoyance has generally been regarded as a dependent variable in noise studies, it might act as an intermediate factor as well (28), as it is likely to have a feedback on the psycho-physiological state and thus on sleep, just as sleep quality has a certain influence on the annoyance level and arousal (29).

An important question is whether noise sensitivity is also associated with other individual traits such as personality that would make it possible to predict individual response to noise in as many situations as possible. It has been shown that tolerance and preference of noise levels differ in introverts and extroverts (30). Introverts have been shown to have a lower optimum arousal threshold and therefore do not need much stimulation before passing their optimal functioning level. Extroverts, in turn, have higher optimum arousal thresholds and therefore tend to seek arousal or stimulating situations. Neuroticism as another basic personality trait is often thought to be reflected in self-oriented thoughts, worry and anxiety, each of which act as a distracter from sound sleep. The personality variable of neuroticism, measured with the Eysenck Personality Inventory Scale, was found to be positively correlated with noise sensitivity and annoyance during noise exposure (31). Arousal in a neurotic person might normally be increased, so the cut-off point that could affect sleep could be more easily induced by noise than in non-neurotic persons.

Taking into account that sensitivity to noise might be responsible for a substantial part of inter-individual 
variance in sleep disturbance induced by noise and that about $20 \%$ of people are more sensitive to noise (32), we suggest that measures to reduce noise exposure should focus on the night time and follow the EU noise directive.

The major limitations of our study are a rather low response rate that might have biased selection; statistically significant differences in average age, apartment size and education between noisy and quiet area residents; we were not able to measure noise inside the flats; and we did not check participants' hearing level.

\section{CONCLUSION}

Our investigation on a sample of residents of Niš, Serbia showed that night traffic noise had significantly deteriorated their quality of sleep. We found that noise sensitivity was an important confounding factor in these effects. We believe that this and our earlier studies on noise and sleep performed in Belgrade provide a sound support for the introduction of the EU Noise Directive 2002/49 in Serbia.

\section{REFERENCES}

1. Miedema HME, Vos H. Associations between self-reported sleep disturbances and environmental noise based on reanalyses of pooled data from 24 studies. Behav Sleep Med 2007;5:1-20.

2. Michaud DS, Fidell S, Pearsons K, Campbell KC, Keith SE. Rewiev of field studies of aircraft noise-induced sleep disturbance. J Acoust Soc Am 2007;121:32-41.

3. Berglund B, Lindvall T, Schwella DH, editors. Guidelines for community noise. Geneva. WHO; 1999.

4. Muzet A. Environmental noise, sleep and health. Sleep Med Rev 2007;11:135-42.

5. Belojević G, Jakovljević B. Factors influencing subjective noise sensitivity in an urban population. Noise Health 2001;4:17-24.

6. Mc Kennel AC, Hunt EA. Noise annoyance in central London. The Government Social Survey, London: HMSO; 1966.

7. Heinonen-Guzejev M. Noise sensitivity - medical, psychological and genetic aspects. Helsinki: Department of Public Health, University of Helsinki; 2008.

8. Weinstein ND. Individual differences in relation to noise: a longitudinal study in a college dormitory. J Appl Psyhol 1978;63:458-66.

9. Griffiths ED, Delauzun FR. Individual differences in sensitivity to traffic noise; an empirical study. J Sound Vib 1977;55:93-107.
10. Stansfeld SA. Sensitivity to noise - source of error or stable personal characteristic. In:Zaniol P, editor. Proceedings of the International Conference "Il rumore urbano e il governo del territorio", Modena, 1-3 March 1988. Milano: Centro Ricerche e Studi Amplifon, 1988. p. 57-64.

11. Middleman HM, Vos H. Noise sensitivity and reactions to noise and other environmental conditions. J Acoust Soc Am 2003;113:1492-504

12. van Kamp I, Job RF, Hatfield J, Haines M, Stellato RK, Stansfeld SA. The role of noise sensitivity in the noiseresponse relation: a comparison of three international airport studies. J Acoust Soc Am 2004;116:3471-9.

13. Belojevic G, Jakovljevic B, Slepcevic V. Noise and mental performance: personality attributes and noise sensitivity. Noise Health 2003;6:3-34.

14. Standard JUS U.J6.090: Akustika u građevinarstvu. Merenje buke u komunalnoj sredini [Acoustics in civil engineering. Measuring environmental noise, in Serbian], 1992.

15. International Organization for Standardization (ISO). Acoustics-Description and measurement of environmental noise - Part I: Basic Quantities and procedures. International Standard. ISO 1996-1. Geneva: ISO; 1982.

16. Standard JUS U.J6.205: Akustika u građevinarstvu. Akustičko zoniranje prostora. [Acoustics in civil engineering. Acoustical spacial zoning, in Serbian], 1992.

17. Ekehammar B, Dornic S. Weinstein's noise sensitivity scale: reliability and construct validity. Percept Mot Skills 1990;70:129-30.

18. Fields JM, de Jong RG, Flindell IH, Gjestland T, Job RFS, Kurra S, Schuemer-Kohrs A, Lercher P, Vallet M, Yano T. Recommendation for shared annoyance questions in noise annoyance surveys. In: Carter N, Job SRF, editors. Noise Effects ' 98 . Proceedings of the $7^{\text {th }}$ International Congress on Noise as a Public Health Problem, Vol 2; 22-6 Nov 1998. Sydney, Australia. Sydney: Noise Effects ‘98 Pty Ltd.; 1998. p. 481-6.

19. Jakovljević B, Belojević G, Paunović K, Stojanov V. Road traffic noise and sleep diturbances in an urban population: cross-sectional study. Croat Med J 2006;47:125-33.

20. Directive 2002/49/EC of the European Parliament and of the Council, of 25 June 2002, relating to assessment and management of environmental noise [displayed 21 July 2009]. Available at http://eur-lex.europa.eu/LexUriServ/ LexUriServ.do?uri=OJ:L:2002:189:0012:0025:EN:PDF.

21. Gonzales LA, Garscia GAM, Redrigues A. Los cambios del sueño produjeron por ruido ambiental [Sleep changes produced by environmental noise, in Spanish]. Gac Sanit 1989;3:421-6.

22. Öhrström E. Sleep disturbance, psycho-social and medical symptoms-a pilot survey among persons exposed to high levels of road traffic noise. J Sound Vib 1989;133:117-28.

23. Franssen EA, van Wiechen CM, Nagelkerke NJ, Lebret E. Aircraft noise around a large international airport and its impact on general health and medication use. Occup Environ Med 2004;61:405-13.

24. Öhrström E. Psychosocial effects of traffic noise exposure. J Sound Vib 1991;151:513-7.

25. Maschke C, Hecht K. Stress hormones and sleep disturbances - electrophysiological and hormonal aspects. Noise Health 2004;6:49-54

26. Marks A, Griefahn B. Associations between noise sensitivity and sleep, subjectively evaluated sleep quality, annoyance, 
and performance after exposure to nocturnal traffic noise. Noise Health 2007;9:1-7.

27. Öhrström E. Effects of low levels from road traffic noise during night- a laboratory study on number of events, maximum noise levels and noise sensitivity. In: Vallet $\mathrm{M}$, editor. Proceeding of the $6^{\text {th }}$ International Congress "Noise as a Public Health Problem"; 5-9 July 1993. Nice, France. Nice: INRETS; 1993. p. 359-66.

28. Gulian E. Psychological consequences of exposure to noise, facts and explanations. In: Ward WD, editor. Proceedings of the $2^{\text {nd }}$ International Congress on Noise as a Public Health Problem; Dubrovnik, Jugoslavia. Washington DC: EPA; 1973. p. 379-87.
29. Dornic S. Mental load, effort and individual differences. Reports from the Department of Psychology, University of Stockholm, No. 509, 1977.

30. Dornic S, Ekehammar B. Extraversion, neuroticism and noise sensitivity. Person Individ Diff 1990;11:989-92.

31. Öhrstöm E, Björkman M, Rylander R. Noise annoyance with regard to neuro-physiological sensitivity, subjective noise sensitivity and personality variables. Psychol Med 1988;18:605-13.

32. Belojević G. Subjektivna osetljivost na buku [Subjective noise sensitivity, in Serbian]. Srpski arhiv za celokupno lekarstvo 1991;119:221-3. 


\section{Sažetak}

\section{DJELOVANJE PROMETNE BUKE NA SPAVANJE GRADSKOGA STANOVNIŠTVA}

Gradska buka je važan ekološki stresni činilac, a poremećaji spavanja su njezin najvažniji učinak na zdravlje ljudi. Velika interindividualna varijacija ovih učinaka može se djelomično objasniti osobnom osjetljivošću na buku. Cilj ove studije bio je procijeniti utjecaj gradske buke na spavanje i povezanost osobne procjene osjetljivosti na buku s poremećajima spavanja. Studija presjeka putem upitnika provedena je na 911 odraslih stanovnika Niša, Srbija, od čega 388 muških (42,6\%) i 523 ženska (57,4\%). Upotrijebljen je upitnik o poremećajima spavanja. Osjetljivost na buku mjerena je Weinsteinovom skalom osjetljivosti na buku. Na osnovi rezultata mjerenja buke, ulice grada Niša označene su kao bučne [noćni ekvivalentni nivo buke (Leq) $>45 \mathrm{~dB}(\mathrm{~A})$ ] i kao tihe [noćni Leq $\leq 45 \mathrm{~dB}(\mathrm{~A})$ ]. Studija je pokazala da su ispitanici iz bučnih ulica izjavili da imaju značajno više teškoća u uspavljivanju, više buđenja, slabiju subjektivnu kvalitetu spavanja, izraženiji umor poslije spavanja i da češće uzimaju lijekove za uspavljivanje u usporedbi sa stanovnicima iz tihih ulica $(\mathrm{p}<0,001)$. Osjetljivost na buku je bila značajno povezana s poremećajima spavanja $(\mathrm{p}<0,001)$.

KLJUČNE RIJEČI: javno zdravlje, odrasli, osjetljivost, poremećaji spavanja, saobraćajna buka

\section{CORRESPONDING AUTHOR:}

Professor Goran Belojević, MD, $\mathrm{PhD}$

Institute of Hygiene and Medical Ecology,

School of Medicine, University of Belgrade

Dr Subotica 8, 11000 Belgrade, Serbia

E-mail: gogibel@eunet.rs 